\title{
Accountability on Sustainability in Central and Eastern Europe: An Empirical Assessment of Sustainability-Related Assurance
}

Oleh Pasko iD https://orcid.org/0000-0002-6275-5885

Ph.D., Assoc. Prof., Sumy National Agrarian University

Faculty of Economics and Management, Department of Accounting and Taxation

Sumy, Ukraine, e-mail: oleh.pasko@snau.edu.ua

Inna Balla iD https://orcid.org/0000-0001-5041-9801

Ph.D., Assistant professor, State Agrarian and Engineering University in Podilya

Faculty of Economics, Department of Accounting, Taxation and E-business

Kamianets-Podilskyi, Ukraine, e-mail: inna.vbm@gmail.com

Inna Levytska iD https://orcid.org/0000-0003-3739-6662

Doctor of Economic Sciences, Full Professor

National University of Life and Environmental Sciences of Ukraine

Educational and Scientific Institute of Continuing Education and Tourism

Department of Agricultural Consulting and Tourism, Kyiv, Ukraine

e-mail: ilevytska@nubip.edu.ua

Nataliia Semenyshena (iD https://orcid.org/0000-0002-0718-0230

Ph.D., Assoc. Prof., State Agrarian and Engineering University in Podilya

Faculty of Economics, Department of Accounting, Taxation and E-business

Kamianets-Podilskyi, Ukraine; Doctoral candidate

Ternopil National Economic University, Department of Accounting and Taxation

Ternopil, Ukraine, e-mail natviksem@gmail.com

\section{Abstract}

The paper explores how companies from Central and Eastern Europe adopt assurance practices to provide accountability for sustainability. Drawing on modified coding rules from prior research, a conventional content analysis of 36 assurance statements 
companies from nine countries was conducted. The results imply differences in the content of reports, processes, and implementation of the standards.

Exclusively large and multinational enterprises from the energy sectors domiciled in Poland and Hungary are a typical portrait of a company from the study's sample, striving to issue and assure sustainability reporting. Of the nine countries represented in the study, sustainability assurance statements of companies from Poland, Hungary, and Romania tend to excel in terms of quality. The vast majority of assurance providers belong to the Big Four, who use ISAE3000 as opposed to AA1100AS. Yet, irrespective of the assurance provider type, stakeholders are neglected. It is argued that just transferring the experience of financial auditing to the field of sustainability, which, by and large, has taken place, is not an option. Authors state that following this route, we are heading in the wrong direction, and in technical terms, the wider proliferation of AA1100AS and its principles, with greater emphasis on reasonable assurance as opposed to the limited and enhanced role of stakeholders, are vital to get back on track.

The paper contributes to the emerging literature on accountability standards and stresses the need to enhance sustainability-related assurance.

Keywords: sustainability reporting, assurance statement, GRI, corporate social responsibility, reporting, auditing

JEL: Q56, M42, O44, O13, 057

\section{Introduction}

Societal pressure and the demand for organizations to be accountable for their social and environmental impact are mounting, and more and more companies respond to these pressures through the issuance of sustainability reports (SRs) (O'Dwyer, Owen, and Unerman 2011; Perego and Kolk 2012; Mikołajek-Gocejna 2016; 2018; Farooq and de Villiers 2019b). Over the past decade, sustainability reporting has morphed into a standard business practice among large global companies (Larrinaga et al. 2020). In its latest global survey, KPMG reports that the sustainability reporting rate in the G250 (250 largest companies by revenue on the Fortune 500) has been stable at between 90 and $95 \%$ in the last four surveys (KPMG 2017).

During the last several decades, we have also observed the rise of international standards in the realm of sustainable development, like the Global Reporting Initiative (GRI) and the AccountAbility AA1000 Assurance Standard (Perego and Kolk 2012; Stocker et al. 2020). According to KPMG's Survey of Corporate Responsibility Reporting 2017, the GRI framework dominates as the framework for SR, as 63\% of 4900 companies researched in the study and $75 \%$ of the 250 largest companies by revenue on the Fortune 500 report applying it. Meanwhile, only $13 \%$ of companies in the study and $12 \%$ of the 250 largest companies use stock exchange guidelines (KPMG 2017, p. 28).

Admitting that some companies may just provide sustainability reporting to "tick a box," and thereby enhance their legitimacy in the eyes of their stakeholders, independ- 
ent sustainability-related assurance has been introduced as a mechanism to mitigate the risk of smoke screening (Ackers 2017a; Rossi and Tarquinio 2017; Boiral, Heras-Saizarbitoria, and Brotherton 2019b; Boiral and Heras-Saizarbitoria 2020). As a result, there is also a growing demand to provide extra credibility to this information through voluntary external assurance (Zorio, García-Benau, and Sierra 2013; Farooq and de Villiers 2019b). KPMG's survey indicates that $67 \%$ of SRs of the G250 included a formal assurance statement, compared with only 30\% in 2005 (KPMG 2017, p. 26).

However, in spite of the steady expansion of SRs, the procedures regulating sustainability-related assurance and its contents are still in their infancy and contain no obligatory requirements whatsoever (O'Dwyer and Owen 2005; O'Dwyer, Owen, and Unerman 2011; Gürtürk and Hahn 2016; Ackers 2017b; Channuntapipat, Samsonova-Taddei, and Turley 2019; 2020; Boiral and Heras-Saizarbitoria 2020). The assurance of SRs remains "a valuable voluntary tool to provide them with higher credibility” (Zorio, García-Benau, and Sierra 2013, p. 484).

Furthermore, along with external transparency, sustainability-related assurance could play a much bigger role in internal sustainability performance measurement and management control. It is believed that companies also seek solid data approved by a third party to inform their decision-making and business strategies (Zorio, García-Benau, and Sierra 2013; Ruiz-Barbadillo and Martínez-Ferrero 2020).

However, vague, unstructured, and unclear sustainability-related assurance statements may miss out relevant information, thereby hollowing out the essence of assurance statements (Gürtürk and Hahn 2016). Prior studies on the issue encouraged studies that could shed light on how various accents on different matters and stipulations impact the value and quality of assurance reports (Zorio, García-Benau, and Sierra 2013; Quick and Inwinkl 2020).

Likewise, several authors questioned whether different frameworks and the applied guidelines and standards affect the provision of assurance statements and whether applied procedures differ depending on the type of assurance provider (Mock, Rao, and Srivastava 2013; Channuntapipat, Samsonova-Taddei, and Turley 2019; 2020; Farooq and de Villiers 2019a; Maroun 2019).

There is real concern that the assurance on sustainability reporting may become a formality, analogous to financial reporting (Boiral and Gendron 2011; Boiral and Heras-Saizarbitoria 2020). Boiral and Gendron (2011, p. 344) emphasize that financial and ISO audits are characterized by significant structural deficiencies, "thereby casting doubt on the exemplification assumption used to justify their import in the sustainability area." In other words, they stress that sustainability auditing is mature enough to become "a site for the reproduction of 'rational myths' that surround the spread of auditing practices in society" (Boiral and Gendron 2011, p. 339). They further claim that "rational myths reflect the ceremonial and superficial adhesion to apparently rational structures and beliefs primarily intended to meet external pressures and reinforce organizational legitimacy, yet they are actually 'decoupled' from organizational practices" (Boiral and Gendron 2011, p. 339). 
The same sentiments are shared by Boiral and Heras-Saizarbitoria (2020, p. 1), who state that "assured sustainability reports ... do not demonstrate a material, substantial, and credible verification process" and that "they tend rather to appear as a hyperreal practice largely divorced from critical sustainability issues and stakeholder concerns."

Against this background, this study aims to provide evidence on the quality of sustainability-related assurance statements in Central and Eastern Europe (CEE). As the quality of assurance reports differs in practice due to various variables, we will dissect this process into components and assess its quality based on the coding rules of Perego and Kolk (2012).

To the best of our knowledge, sustainability-related assurance in CEE has not been the subject of peer-review study so far, and research on sustainability-related assurance remains limited in scope and breadth (Hahn and Kühnen 2013). The trend for sustainability-related assurance in this region is not felt so urgently as in Western Europe and Northern America. As Gheorghita Diaconu, Director of Sustainability Services of KPMG in Romania, stated: "Many businesses in Eastern Europe are still focused on the financial bottom line rather than the triple bottom line - it's fair to say that a culture of sustainability is yet to properly take hold across the region" (KPMG 2017, p. 14). This is confirmed by the data: sustainability reporting rate in Western Europe equals 82\%, while in Eastern Europe - 65\% (KPMG 2017, p. 14). In terms of countries from CEE in 2017 sustainability reporting rate was Hungary 77\%, Romania - 74\%, Poland - 59\%, Czech Republic - 51\%, Slovakia - 55\% (KPMG 2017, p. 16).

Nevertheless, this fledgling field is steadily developing, and more and more companies are joining the ranks of sustainability reporting firms each year. One of the connotations of "fledgling" is to be malleable, and it is why it is very important to study this phenomenon in order to be able to correct the projection of its developments if necessary.

The focus of this paper is sustainability assurance in the reporting of companies from CEE. Therefore, this paper critically appraises the value to users and the quality of the information in sustainability-related assurance statements to understand current sustainability assurance practices in CEE.

This focus is instrumental for us to achieve the following research goals. First, the study concerns itself with the differences in assurance practices and has a goal to enrich prior study findings through extending the study base by including companies of CEE and by explicating these differences. The paper explicates whether different assurance providers and assurance standards are related to the assured content, work performed, and overall quality of assurance statements.

Second, the paper appraises the quality of assurance reports, which are assessed against the coding rules developed by Perego and Kolk (2012) to provide a clue whether the quality of assurance hinges on the assurance provider of reports (Accountants vs. Non-accountants), addressees of assurance statement (Management, Shareholders, Stakeholders), applied standards (AA1000, ISAE3000, ISRS 4400), and other variables. 
Therefore, the underlying motive of this study is to provide additional evidence on the practice and quality of assurance reports in CEE. We presuppose that providing such a look at assurance practice has implications for the perceived nature of this practice as well as for the reliance placed on assurance statements and appraisal of the information assured.

Achieving these two goals would also mean ascertaining how contemporary assurance practices in CEE impact expected information benefits for management and stakeholders. The conclusions of the paper provide an examination of the information value of assurance statements for external users.

To accomplish these goals, this study uses coding rules developed by prior studies (mostly Perego and Kolk 2012) and employs deductive content analysis on the sustainability-related assurance reports by CEE companies from the GRI Sustainability Disclosure Database (SDD). We limit ourselves only to SRs based on GRI standards - the latest guidelines developed by the Global Sustainability Standards Board. The object of this study is 15 countries: Belarus, Bulgaria, Croatia, the Czech Republic, Estonia, Hungary, Latvia, Lithuania, Moldova, Montenegro, Poland, Romania, Slovakia, Slovenia, and Ukraine.

Specifically, the paper examines the information that is subject to external assurance: the scope and level of assurance, the applied assurance standards, and the varieties of assurance engagement forms. The study also analyzes the assurance provider and the effect of various types of assurance provider on assurance quality. It also scrutinizes the addressees of assurance statement and evaluates the variability of the assurance statements content and, through it, assess the transparency of assurance statements and their usefulness for stakeholders and internal management.

The article is structured as follows. The paper commences with a review of the relevant literature that provides the theoretical framework used in this study. This is followed by content analysis and descriptive results of the study. The final section discusses the findings and concludes with consequences for theory and practice.

\section{Conceptual background and theory}

The assurance of sustainability reporting by a third party is widely believed to be the proper response that can restore and enhance public confidence in SRs (Gürtürk and Hahn 2016; Boiral, Heras-Saizarbitoria, and Brotherton 2019a; Farooq and de Villiers 2019b; Michelon, Patten, and Romi 2019; Haider and Nishitani 2020; Maroun 2020).

The need to increase the reliability of SRs is clearly evident in the rapid increase in the number of SRs that were accompanied by an assurance report. In 2017 (latest available report), $67 \%$ of the sustainability reports of the G250 companies included a formal assurance statement, compared with only 30\% in 2005 (KPMG 2017, p. 26). In N100 companies (3543 companies studied), the sustainability reporting rate is also 
steadily growing, reaching $45 \%$ in 2017 - up 12 percentage points compared to the 2005 level (33\%) (KPMG 2017, p. 26).

Many authors also believe that such an increase attests to the development of the "audit society" first discerned by Michael Power $(1997$; 1999) in the late 1990s (Boiral, Heras-Saizarbitoria, and Brotherton 2019a). It also testifies to the predominance of accountancy organizations, which represent $75 \%$ of SR assurance providers (KPMG 2017; Boiral, Heras-Saizarbitoria, and Brotherton 2019a; Channuntapipat, Samsonova-Taddei, and Turley 2020). This emphasis on the practices and institutional arrangements that were first brought to life and are now prevalent in finance is a hallmark of the "audit society". This hallmark is also manifested through the fact that although sustainability assurance is based on specific standards (AA1000 and ISAE 3000), these standards are in turn, based on general auditing principles, i.e., ethical principles, the independence and impartiality of auditors, the scope of an engagement, different levels of assurance, and even the structure of the assurance statements (Boiral, Heras-Saizarbitoria, and Brotherton 2019a; Channuntapipat, Samsonova-Taddei, and Turley 2020).

Although the external evaluation of SRs is still controversial, most researchers agree that such assurance is useful and even necessary (Fédération des Experts Comptables Européens 2006; Jones and Solomon 2010; Boiral, Heras-Saizarbitoria, and Brotherton 2019a; 2019b; Farooq and de Villiers 2019a; Channuntapipat, Samsonova-Taddei, and Turley 2020). This is because, by giving their opinions, assurance providers are believed to reduce uncertainty and inherent information asymmetry which inevitably arises between managers and stakeholders (O'Dwyer, Owen, and Unerman 2011; Moroney, Windsor, and Aw 2012; Gürtürk and Hahn 2016; Boiral, Heras-Saizarbitoria, and Brotherton 2019a). The next positive impact linked to sustainability-related assurance is caused by its disciplinary effect on the company since it is believed that auditor scrutiny persuades companies to enhance and fine-tune their sustainability reporting approach (Park and Brorson 2005; Haider and Nishitani 2020; Nishitani, Haider, and Kokubu 2020).

Further, it should be noted that because some assurance standards contain requirements for stakeholder inclusivity and responsiveness, the assurance process increases the level of consultation with the stakeholders (Park and Brorson 2005; Haider and Nishitani 2020; Nishitani, Haider, and Kokubu 2020). The latter effect follows from the external verification procedure itself, which involves interviews with stakeholders, primarily internal (employees) ones, but also external. All this leads to the internalization of GRI principles and it, in turn, could usher in the era of stakeholder responsiveness in companies, and, as a result, sustainability-related assurance guides companies into genuine stakeholders' accountability (Boiral, Heras-Saizarbitoria, and Brotherton 2019a).

However, the literature also contains critical authors who see many flaws in sustainability-related assurance. One of the weaknesses of sustainability-related assurance that compromises the whole process, and which was inherited from financial audits, 
is that the assurance provider is financially dependent on the customer (O'Dwyer, Owen, and Unerman 2011; Perego and Kolk 2012; Boiral, Heras-Saizarbitoria, and Brotherton 2019a; Nishitani, Haider, and Kokubu 2020). Such financial relationships push the auditor to behave uncritically when he does not seriously question the reliability of the data provided. The auditor's financial dependence on the companies may eventually lead to a situation where skepticism and impartiality - the cornerstones of assurance - would be compromised (Gilbert, Rasche, and Waddock 2011; Boiral, Heras-Saizarbitoria, and Brotherton 2019a; Haider and Nishitani 2020).

Several papers emphasize the managerial capture of information in sustainability reporting as a reason for it not being as efficient as it might otherwise be (O'Dwyer and Owen 2007; Jones and Solomon 2010; Smith, Haniffa, and Fairbrass 2011; Farooq and de Villiers 2019a). The managerial capture is manifested in the fact that managers have control over the information, and the auditor, in turn, must rely on his/her assessment of this information, which can be limited or distorted in a way that will benefit the managers (Smith, Haniffa, and Fairbrass 2011).

The third aspect that must be highlighted is the professionalism of assurance providers and the rigor of the practice (Park and Brorson 2005; Smith, Haniffa, and Fairbrass et al. 2011; Boiral, Heras-Saizarbitoria, and Brotherton 2019a; Ruiz-Barbadillo and Martínez-Ferrero 2020). Unlike in financial auditing, sustainability assurance is not so developed because it is not based on one generally accepted standard, nor is the professional self-organization at the proper level. In financial auditing, for example, there are minimum requirements for experience and training that an auditor must meet in order to be admitted to practice; that is not the case in sustainability assurance. Many auditors view this process as a continuation of the financial audit, but this is only partially true. As a result, many sustainability-related assurances are carried out superficially just to obtain a certificate, get the label "is verified," and thereby enhance the social legitimacy of reporting companies (Park and Brorson 2005; Smith, Haniffa, and Fairbrass 2011; Boiral, Heras-Saizarbitoria, and Brotherton 2019a; Boiral and Heras-Saizarbitoria 2020; Ruiz-Barbadillo and Martínez-Ferrero 2020).

Perego and Kolk (2012) even claim that "managerial capture" and "rational myths of certification" are produced, sustained, and become institutionalized over time" (Perego and Kolk 2012, p. 176). Such behavior has long been known and fully falls under the explanation of the legitimacy theory, which claims that many companies, under strong institutional pressure, superficially adopt new practices to increase their social legitimacy (Smith, Haniffa, and Fairbrass 2011; Boiral, Heras-Saizarbitoria, and Brotherton 2019a; Safari and Areeb 2020).

Despite this ambiguity in the development of sustainability-related assurance, most studies do not critically question the value, significance, or legitimacy of third-party assurance on sustainability reporting. 


\section{Methods}

This study applies deductive content analysis to sustainability-related assurance statements published using GRI standards by CEE companies retrieved from the GRI Sustainability Disclosure Database (SDD). To ensure the relevance of the study, we limit ourselves only to SRs based on GRI standards - the latest guidelines developed by the Global sustainability standards board. Issued in 2016 and effective (with exception) from 1 Jul 2018, the GRI standards represent the latest development in the sustainability reporting framework. The object of our study is 15 countries: Belarus, Bulgaria, Croatia, the Czech Republic, Estonia, Hungary, Latvia, Lithuania, Moldova, Montenegro, Poland, Romania, Slovakia, Slovenia, and Ukraine (Table 1).

Table 1. Companies from Central and Eastern Europe in the GRI database

\begin{tabular}{|l|c|c|c|c|}
\hline & Organizations & $\begin{array}{c}\text { Sustainability } \\
\text { Reports }\end{array}$ & Assured reports & $\begin{array}{c}\text { Available for } \\
\text { analysis reports }\end{array}$ \\
\hline Belarus & 0 & 0 & 0 & 0 \\
\hline Bulgaria & 0 & 0 & 0 & 0 \\
\hline Croatia & 5 & 8 & 3 & 2 \\
\hline Czech Republic & 12 & 17 & 4 & 3 \\
\hline Estonia & 2 & 2 & 1 & 1 \\
\hline Hungary & 13 & 23 & 12 & 9 \\
\hline Latvia & 4 & 6 & 5 & 4 \\
\hline Lithuania & 5 & 5 & 0 & 0 \\
\hline Moldova & 0 & 0 & 0 & 0 \\
\hline Montenegro & 0 & 0 & 0 & 12 \\
\hline Poland & 50 & 66 & 13 & 1 \\
\hline Romania & 13 & 22 & 3 & 0 \\
\hline Slovakia & 0 & 0 & 0 & 1 \\
\hline Slovenia & 6 & 12 & 3 & 36 \\
\hline Ukraine & 2 & 4 & 1 & 45 \\
\hline Total & 112 & 165 & & 0 \\
\hline
\end{tabular}

Source: Prepared by authors based on data derived from https://database.globalreporting.org/ (accessed: 16.06.2020).

We used the GRI SDD search engine, and our search filter was arranged as follows: size: no selection; sector: no selection; country: 15 mentioned countries; region: no selection; report type: GRI - Standards; reporting year: no selection. The search returned 112 organizations that submitted 165 SRs. Only 45 (27.3\%) of those reports were assured, and due to the inability to retrieve assurance statements (in three instances) and the fact that the language of assurance statements was unintelligible for the authors (six instances), our population was reduced by nine; our final sample totals 36 assurance statements.

In order to determine the quality of the assurance statements, this study applied 19 coding rules originally proposed O'Dwyer and Owen (2005) and modified by Per- 
ego and Kolk (2012) and four coding rules put forward by Gürtürk and Hahn (2016). In total, we have at our disposal 23 coding rules that define the quality of assurance statements based on the AccountAbility, Federation of European Accountants, and GRI guidelines. The maximum score an assurance report could get according to our coding rules is 35 points.

The use of these codes not only allowed us to analyze reports on various grounds but also allowed us to rank the reports and identify patterns. We employ "conventional content analysis," according to the classification of Hsieh and Shannon (2005), and followed the guidelines of standard content analysis methodology (Hsieh and Shannon 2005).

In total, four people were involved in the coding process, among them two authors of the article and two independent coders. This was the basis that allowed personal assessment to give way to abstract estimation and to obtain inter-subjective judgments (Gürtürk and Hahn 2016). To ensure replicability and the reliability of the study, the research process was reinforced with circumstantial documentation throughout the entire process.

\section{Results}

The results of our study can be presented in three subsections, which will contribute to a clearer presentation of the material. In the first section, we describe the overall results of our study. This subsection is followed by an analysis of the assurance reports' transparency, which is assessed based on the coding rules. The third subsection depicts the relationships between the given feature of the reports and their quality.

\section{General features of the assurance reports}

The descriptive statistics of our sample are provided in Table 3, and they serve as a reference point to quickly grasp the features and attributes of our sample. The descriptive statistics of companies with assured SRs comprises two groups: all assured SRs (45) and those available for analysis (36).

Each report begins with the addressee, to whom it is addressed, which, as we later see, is already the first harbinger of quality. During coding, we identified three groups to whom the SRs can be addressed: 1) the reporting company (management, board of directors, shareholders), 2) the general public or all stakeholders, and 3) no addressee mentioned. The vast majority of reports in our sample (25) are addressed to management, only five are addressed to stakeholders, and four mention no addressee at all (Table 3). 
Oleh Pasko, Inna Balla, Inna Levytska, Nataliia Semenyshena

Table 2. Descriptive statistics of companies with assured sustainability reports

\begin{tabular}{|c|c|c|c|c|c|c|c|c|c|}
\hline \multicolumn{7}{|c|}{ Reporting year } & & & \\
\hline 2019 & 2018 & 2017 & $2017 / 2018$ & $2016 / 2017$ & 2016 & Total & & & \\
\hline 3 & 19 & 14 & 2 & 2 & 5 & 45 & & & \\
\hline 3 & 17 & 12 & 1 & 1 & 2 & 36 & & & \\
\hline \multicolumn{4}{|c|}{ Size } & & & & & & \\
\hline Large & MNE & SME & Total & & & & & & \\
\hline 33 & 11 & 1 & 45 & & & & & & \\
\hline 25 & 11 & 0 & 36 & & & & & & \\
\hline \multicolumn{10}{|c|}{ Sector } \\
\hline 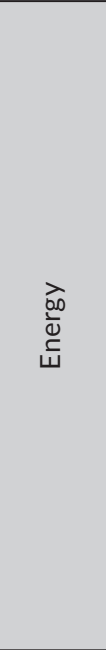 & $\begin{array}{l}\frac{\tilde{E}}{0} \\
\frac{\mathcal{U}}{\mathscr{E}}\end{array}$ & 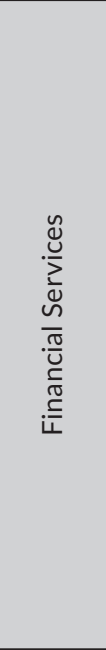 & 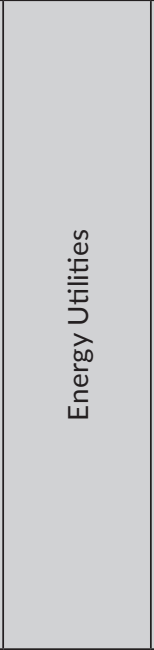 & $\frac{\frac{n}{0}}{\frac{\pi}{\pi}}$ & 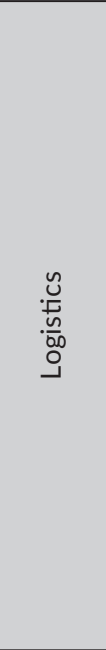 &  &  & 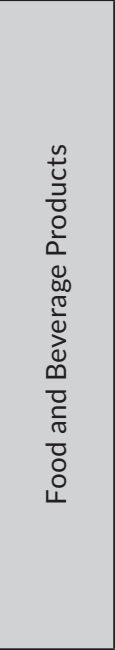 & $\begin{array}{l}\bar{\pi} \\
0 \\
1\end{array}$ \\
\hline 13 & 7 & 5 & 4 & 4 & 2 & 2 & 7 & 1 & 45 \\
\hline 11 & 7 & 3 & 3 & 1 & 2 & 2 & 7 & 0 & 36 \\
\hline \multicolumn{10}{|c|}{ Country } \\
\hline Croatia & $\begin{array}{l}\text { Czech } \\
\text { Repub- } \\
\text { lic }\end{array}$ & Estonia & Hungary & Latvia & Poland & $\begin{array}{c}\text { Roma- } \\
\text { nia }\end{array}$ & $\begin{array}{c}\text { Slove- } \\
\text { nia }\end{array}$ & Ukraine & Total \\
\hline 3 & 4 & 1 & 12 & 5 & 13 & 3 & 3 & 1 & 45 \\
\hline 2 & 3 & 1 & 9 & 4 & 12 & 1 & 3 & 1 & 36 \\
\hline
\end{tabular}

Source: own calculations based on data derived from https://database.globalreporting.org/ (accessed: 16.06.2020).

Table 3. General details of assurance statements

\begin{tabular}{|l|l|}
\hline \multicolumn{1}{|c|}{ Criteria } & \multicolumn{1}{|c|}{ Features } \\
\hline $\begin{array}{l}\text { Addressees of statement } \\
\text { (available reports only) }\end{array}$ & - Reporting company (27) \\
& - management (25) \\
& - board of directors (1) \\
& - shareholders (1) \\
& - General public or all stakeholders (5) \\
& - No addressee mentioned (4) \\
\hline
\end{tabular}




\begin{tabular}{|l|l|}
\hline \multicolumn{1}{|c|}{ Criteria } & \multicolumn{1}{c|}{ Features } \\
\hline Type of assurer & - Accounting firm (33) \\
& - Small consultancy/ boutique firm (11) \\
- Engineering firm (1)
\end{tabular}

Source: own calculations based on data derived from https://database.globalreporting.org/ (accessed: 16.06.2020).

The sustainability assurance market is fragmented, with various types of sustainability assurance providers competing with each other and using different approaches, guidelines, and standards to meet the needs of various customers (Farooq amd de Villiers 2019c). The market is also poorly regulated, if not completely unregulated, indicating the presence of different sustainability assurance providers. In our sample, the Big Four companies still dominate the field as the assurance providers in $73.3 \%$ of cases, while small consultancy/boutique firms and engineering firms assured only 12 SRs. Deloitte has the biggest slice, as the assurance provider in slightly more than $1 / 3$ of the cases we analyzed. Ernst \& Young follows suit with eight reports $(17.8 \%)$, while PricewaterhouseCoopers closes the biggest three sustainability providers of our sample with seven reports (15.6\%).

A limited/moderate level of assurance prevails among the analyzed sustainability assurance reports - 38 cases (84.4\%), while only two assurance reports could boast reasonable assurance, although combined with limited/moderate assurance. In four reports (8.9\%), the level of assurance is not specified, which runs counter to whatever possible standards.

The coverage or assurance scope is also an important aspect of a sustainability assurance report, revealing how deep auditors dig while on the engagement. Most of the analyzed assurance reports (32 instances, i.e., 71.1\%) cover only specified section(s), while the entire SR is covered in 10 instances (22.2\%). Only two companies did not 
specify the assurance scope, and one spread its opinion on Greenhouse Gas (GHG) protocol only.

The assurance standards were clearly indicated in 39 reports (86.7\%), and mention of it was omitted in 6 (13.3\%). An overwhelming majority of auditors make use of ISAE3000, as this standard, along with or in combination with others, is mentioned 34 times (75.6\%). The more robust and more specialized sustainability auditing AA1000AS, alone or combined with other standards, is mentioned in only six instances (13.3\%). What surprised us was the application of ISRS 4400, employed once by one of the Big Four companies.

\section{Analysis of the assurance reports' transparency}

All these above-described factors were also taken into account in our coding rules, which were developed based on the requirements of the AccountAbility, Federation of European Accountants, and GRI guidelines. The highest possible score our coding rules allowed is 35 points. All reports available for analysis were scored against the coding rules, and this resulted in an overall mean of 16.58 , with a standard deviation of 2.73. The most comprehensive statements in the sample scored 25 points, while the least transparent managed to get only nine points (Table 4).

The report that scored 25 points achieved only $71.4 \%$ from the available 35 , which poses the perennial question "why?" In answering this question, it is imperative to understand how particular features of the assurance report affected its transparency and quality. The quality score of the assurance reports hinges on various attributes, and the next subsection of the results section is devoted exactly to that enterprise. Our results are consistent with prior studies, drawing on content analysis like Gürtürk and Hahn (2016) and Perego and Kolk (2012). The overall mean in Gürtürk and Hahn's study was 16.86, with a standard deviation of 5.41 (Gürtürk and Hahn 2016, p. 35). The overall mean in Perego and Kolk's study was 11.87, with a standard deviation of 5.31 (Perego and Kolk 2012, p. 182). If we consider that the last authors carried out research for several years (beginning in 1999, i.e., when there was no GRI), it is not surprising that the quality is improving. However, it should be noted that the objects of analysis were different in all of these studies, which makes comparison impossible. 
Accountability on Sustainability in Central and Eastern Europe...

\begin{tabular}{|c|c|c|c|c|c|c|c|c|c|c|c|c|c|c|c|c|c|c|c|c|c|c|c|c|}
\hline ริ & 0 & 0 & 0 & 0 & 0 & 0 & 0 & & 0 & 0 & 0 & -1 & 0 & 0 & 0 & 0 & 0 & 0 & 0 & -1 & 0 & 0 & 0 & 0 \\
\hline N & 0 & | & 0 & 0 & 0 & $c$ & & & -1 & 0 & 0 & -1 & 0 & 0 & 0 & 0 & 0 & 0 & 0 & -1 & -1 & -1 & 0 & 0 \\
\hline ต & 0 & c & 0 & 0 & 0 & & & & 0 & 0 & 0 & ○ & 0 & 0 & 0 & 0 & 0 & 0 & 0 & -1 & 0 & 0 & 0 & 0 \\
\hline 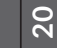 & -1 & $r$ & -1 & -1 & -1 & & & & 0 & -1 & -1 & -1 & -1 & -1 & -1 & -1 & -1 & -1 & -1 & 0 & -1 & -1 & $\rightarrow$ & - \\
\hline ने & -1 & -1 & -1 & -1 & -1 & & & & $\neg$ & -1 & -1 & -1 & -1 & -1 & -1 & -1 & -1 & -1 & -1 & $N$ & -1 & -1 & $\rightarrow$ & - \\
\hline$\stackrel{\infty}{\sim}$ & 0 & 0 & 0 & 0 & 0 & $c$ & & & 0 & 0 & 0 & -1 & 0 & 0 & 0 & 0 & 0 & 0 & 0 & -1 & -1 & -1 & 0 & 0 \\
\hline $\mathrm{A}$ & 0 & 0 & 0 & 0 & 0 & $c$ & & & 0 & 0 & 0 & -1 & 0 & 0 & 0 & 0 & 0 & 0 & 0 & -1 & -1 & -1 & 0 & 0 \\
\hline 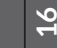 & 0 & 0 & 0 & 0 & 0 & $c$ & & & 0 & 0 & 0 & -1 & 0 & 0 & 0 & 0 & -1 & 0 & 0 & -1 & -1 & -1 & 0 & 0 \\
\hline$\stackrel{19}{\sim}$ & v & $\sim$ & $N$ & $\sim$ & $\sim$ & s & & & $N$ & $N$ & $\sim$ & $N$ & $\sim$ & $N$ & $\sim$ & $N$ & $\sim$ & $\sim$ & $N$ & $N$ & $\sim$ & $N$ & $\sim$ & $N$ \\
\hline 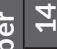 & - & -1 & -1 & -1 & -1 & 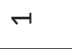 & & & 0 & -1 & -1 & -1 & -1 & -1 & -1 & -1 & -1 & -1 & -1 & -1 & -1 & -1 & $\rightarrow$ & -1 \\
\hline 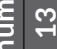 & -1 & -1 & -1 & -1 & -1 & - & & & -1 & -1 & -1 & -1 & -1 & -1 & -1 & -1 & $\sim$ & -1 & -1 & -1 & -1 & -1 & $\rightarrow$ & -1 \\
\hline ㄱ & 0 & c & 0 & 0 & 0 & & & & 0 & 0 & 0 & -1 & 0 & 0 & 0 & 0 & -1 & 0 & 0 & $N$ & 0 & 0 & 0 & 0 \\
\hline$\vec{F}$ & -1 & -1 & $r$ & -1 & -1 & & & & 0 & -1 & -1 & -1 & -1 & -1 & -1 & -1 & -1 & -1 & -1 & $N$ & $N$ & $N$ & $\rightarrow$ & -1 \\
\hline 0 & -1 & 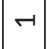 & 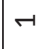 & -1 & -1 & & & & $\neg$ & -1 & -1 & -1 & -1 & -1 & -1 & -1 & -1 & -1 & -1 & -1 & -1 & -1 & $\rightarrow$ & -1 \\
\hline a & 0 & & 0 & 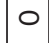 & 0 & & & & 0 & 0 & 0 & -1 & 0 & 0 & 0 & 0 & 0 & 0 & 0 & 0 & 0 & 0 & 0 & 0 \\
\hline$\infty$ & 0 & . & 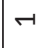 & 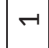 & -1 & & & & 0 & -1 & -1 & -1 & -1 & -1 & -1 & $\neg$ & -1 & -1 & -1 & -1 & -1 & -1 & $\rightarrow$ & -1 \\
\hline N & -1 & -1 & -1 & -1 & -1 & & & & $\neg$ & -1 & -1 & -1 & -1 & $\neg$ & -1 & $\neg$ & -1 & -1 & -1 & -1 & -1 & -1 & $\rightarrow$ & -1 \\
\hline ○ & -1 & -1 & -1 & 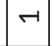 & -1 & & & & -1 & -1 & -1 & -1 & -1 & -1 & -1 & $\neg$ & -1 & -1 & -1 & -1 & -1 & -1 & -1 & -1 \\
\hline in & -1 & . & -1 & 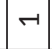 & -1 & & & & $\neg$ & -1 & -1 & 0 & -1 & -1 & -1 & -1 & -1 & -1 & -1 & -1 & -1 & -1 & $\rightarrow$ & -1 \\
\hline$\nabla$ & - & . & 0 & 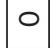 & -1 & & & & $\neg$ & -1 & -1 & -1 & -1 & -1 & -1 & -1 & 0 & -1 & -1 & -1 & -1 & -1 & -1 & -1 \\
\hline 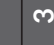 & 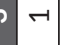 & - & -1 & 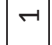 & -1 & & & & -1 & -1 & -1 & -1 & -1 & -1 & -1 & $\neg$ & -1 & -1 & -1 & -1 & -1 & -1 & $\rightarrow$ & -1 \\
\hline v & -1 & . & $\neg$ & 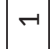 & -1 & & & & 0 & -1 & -1 & -1 & -1 & -1 & -1 & -1 & $\sim$ & -1 & -1 & -1 & -1 & -1 & -1 & -1 \\
\hline & -1 & -1 & $\neg$ & -1 & -1 & & & & -1 & -1 & -1 & -1 & -1 & -1 & -1 & -1 & -1 & -1 & -1 & -1 & -1 & -1 & -1 & -1 \\
\hline  & - & $\mid \stackrel{0}{-1}$ & $\stackrel{1}{\sim}$ & 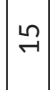 & $\stackrel{0}{\sim}$ & $\stackrel{1}{\rightarrow}$ & & 0 & $\underset{\sim}{*}$ & 임 & $|\stackrel{0}{-1}|$ & N & $\mid \stackrel{0}{-1}$ & - & $\stackrel{0}{-1}$ & $\mid \begin{array}{l}0 \\
-1\end{array}$ & 잉 & - & $\stackrel{0}{-1}$ & 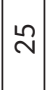 & $\vec{N}$ & $\vec{N}$ & 익. & 帝 \\
\hline C & 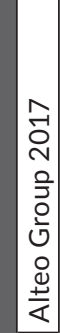 & 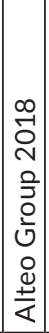 & 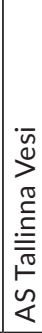 & $\mid \begin{array}{l}\frac{\pi}{2} \\
\frac{1}{5} \\
\frac{\pi}{4} \\
\mid\end{array}$ & 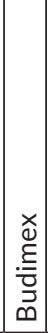 & 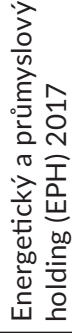 & 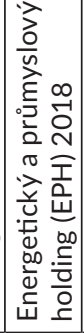 & 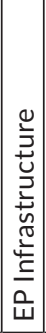 & 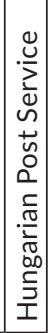 & 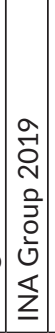 & 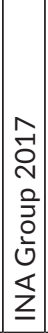 & 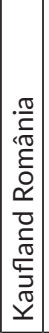 & 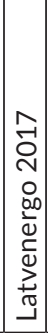 & 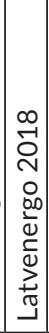 & 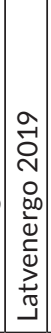 & 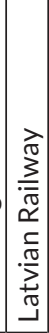 & 谷 & 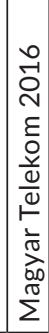 & 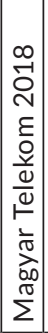 & 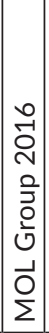 & 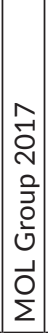 & 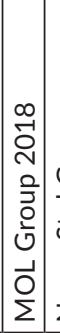 & 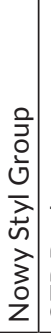 & 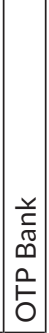 \\
\hline & & N & (n) & $\nabla$ & in & & $r$ & $\infty$ & $\sigma$ & 어 & $\exists$ & ન & $\stackrel{m}{\rightarrow}$ & $\vec{A}$ & $\stackrel{\sim}{\sim}$ & $\begin{array}{l}0 \\
-1\end{array}$ & А & $\stackrel{\infty}{\sim}$ & ने & ㅇ & $\vec{N}$ & $\approx$ & $\stackrel{m}{N}$ & $\stackrel{d}{\sim}$ \\
\hline
\end{tabular}




\begin{tabular}{|c|c|c|c|c|c|c|c|c|c|c|c|c|}
\hline $\mathscr{N}$ & -1 & -1 & -1 & 0 & 0 & 0 & 0 & 0 & 0 & 0 & 0 & 0 \\
\hline$N$ & -1 & -1 & -1 & 0 & 0 & 0 & 0 & 0 & 0 & 0 & 0 & 0 \\
\hline $\overrightarrow{\mathrm{N}}$ & 0 & 0 & 0 & 0 & 0 & 0 & 0 & 0 & 0 & 0 & 0 & 0 \\
\hline 오 & -1 & -1 & -1 & -1 & $r$ & $r$ & $r$ & 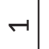 & -1 & $r$ & - & - \\
\hline a & -1 & -1 & -1 & -1 & $r$ & $r$ & $r$ & $r$ & -1 & $r$ & $-r$ & 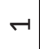 \\
\hline$\stackrel{\infty}{\sim}$ & 0 & 0 & 0 & 0 & 0 & 0 & 0 & 0 & 0 & 0 & 0 & 0 \\
\hline 각 & 0 & 0 & 0 & 0 & 0 & 0 & 0 & 0 & 0 & 0 & 0 & 0 \\
\hline$\stackrel{\circ}{\sim}$ & -1 & -1 & -1 & 0 & 0 & 0 & -1 & $\neg$ & 0 & $r$ & 0 & 0 \\
\hline 욕 & -1 & -1 & -1 & $N$ & $\sim$ & $N$ & $N$ & $N$ & $N$ & $N$ & $N$ & $N$ \\
\hline ১) & 0 & 0 & 0 & -1 & -1 & -1 & -1 & -1 & -1 & $r$ & -1 & -1 \\
\hline ह & -1 & -1 & -1 & $r$ & -1 & $\neg$ & $\sim$ & $N$ & $\neg$ & $\sim$ & -1 & -1 \\
\hline$\frac{0}{3} \underset{ }{N}$ & -1 & 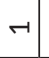 & -1 & 0 & 0 & 0 & $r \mid$ & 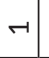 & 0 & $r 1$ & 0 & 0 \\
\hline 응 궁 & 0 & 0 & 0 & $r$ & $\neg 1$ & $\neg$ & $\neg 1$ & $r$ & $\neg$ & $\neg 1$ & -1 & -1 \\
\hline ن음 & 0 & 0 & 0 & -1 & -1 & -1 & $r$ & $r$ & $\neg$ & $r$ & $r$ & -1 \\
\hline a & -1 & -1 & -1 & 0 & 0 & 0 & 0 & 0 & 0 & 0 & 0 & 0 \\
\hline$\infty$ & -1 & -1 & -1 & -1 & -1 & -1 & -1 & -1 & $\neg$ & $r$ & - & -1 \\
\hline$\Lambda$ & -1 & -1 & -1 & -1 & -1 & -1 & -1 & -1 & $\neg$ & $r$ & -1 & -1 \\
\hline$\bullet$ & -1 & -1 & -1 & -1 & -1 & -1 & -1 & $\rightarrow$ & -1 & -1 & -1 & -1 \\
\hline in & -1 & -1 & -1 & -1 & -1 & -1 & -1 & -1 & -1 & -1 & - & -1 \\
\hline 寸 & 0 & 0 & 0 & -1 & -1 & -1 & 0 & 0 & -1 & 0 & -1 & -1 \\
\hline$m$ & -1 & -1 & -1 & -1 & -1 & -1 & -1 & -1 & -1 & $r$ & -1 & -1 \\
\hline$N$ & 0 & 0 & 0 & -1 & -1 & -1 & $N$ & $N$ & $\neg$ & $N$ & -1 & -1 \\
\hline-1 & -1 & -1 & -1 & -1 & -1 & -1 & -1 & -1 & -1 & -1 & -1 & -1 \\
\hline 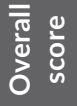 & $\stackrel{1}{-1}$ & $\stackrel{\sim}{\sim}$ & $\stackrel{n}{\sim}$ & $\stackrel{+}{\circ}$ & $\stackrel{0}{\circ}$ & $\stackrel{0}{\circ}$ & 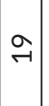 & $\stackrel{a}{\sim}$ & $\stackrel{0}{\sim}$ & $\stackrel{9}{-1}$ & $\stackrel{0}{-1}$ & $\stackrel{\circ}{\sim}$ \\
\hline हु & 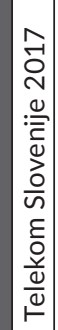 & 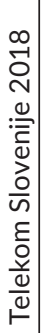 & 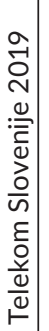 & 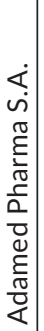 &  & $\begin{array}{l}\frac{\pi}{v} \\
\frac{v}{0} \\
0 \\
0 \\
0 \\
00 \\
\frac{1}{0} \\
\frac{0}{0}\end{array}$ & $\begin{array}{c}\frac{\pi}{v} \\
\frac{v}{0} \\
0 \\
0 \\
0 \\
00 \\
\frac{1}{0} \\
0\end{array}$ & $\begin{array}{l}\stackrel{\sigma}{E} \\
\frac{\delta}{\sigma} \\
\frac{0}{0} \\
\frac{0}{0} \\
\Omega\end{array}$ & $\begin{array}{l}\frac{1}{c} \\
\frac{0}{0} \\
\frac{0}{2} \\
0 \\
\frac{0}{2}\end{array}$ & w & $\begin{array}{l}\frac{0}{3} \\
\frac{0}{1} \\
\frac{1}{0} \\
\frac{1}{0} \\
\frac{0}{\pi} \\
\frac{1}{\sim}\end{array}$ & 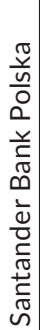 \\
\hline & $\stackrel{\sim}{\sim}$ & $\stackrel{\circ}{v}$ & $\lesssim$ & $\stackrel{\infty}{N}$ & 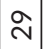 & ○ & $\vec{m}$ & ले & $m$ & गे & ๓n & లొ \\
\hline
\end{tabular}




\section{Relationships between the given feature of the reports and their quality}

In these pages, we will analyze the differences between the assurance reports on two sets of criteria. The first simply helps us to understand the state of sustainability-related assurance in CEE, and the second directly affects the quality of the report. Let us start with the former and conclude with the latter.

This study analyzes the assurance statements that back sustainability reporting according to GRI Standards issued by CEE companies retrieved from the GRI Sustainability Disclosure Database (SDD). We initially analyzed fifteen countries, but due to the lack of data in six of them, our sample includes only nine countries (Table 5).

Table 5. Differences between countries

\begin{tabular}{|c|c|c|c|c|c|c|}
\hline \multirow[b]{2}{*}{ Country } & \multirow[b]{2}{*}{$\begin{array}{l}\text { Sustainability } \\
\text { reports }\end{array}$} & \multirow[b]{2}{*}{$\begin{array}{l}\text { Assured } \\
\text { reports }\end{array}$} & \multicolumn{2}{|c|}{ Assured reports } & \multirow{2}{*}{$\begin{array}{c}\text { Average } \\
\text { overall } \\
\text { assurance } \\
\text { quality score }\end{array}$} & \multirow{2}{*}{$\begin{array}{c}\text { Standard } \\
\text { deviation } \\
\text { per } \\
\text { standard }\end{array}$} \\
\hline & & & $\begin{array}{c}\text { Absolute } \\
\text { count }\end{array}$ & $\begin{array}{l}\text { Relative } \\
\text { count }\end{array}$ & & \\
\hline Poland & 66 & $19.7 \%$ & 12 & $33.3 \%$ & 17.00 & 1.48 \\
\hline Hungary & 23 & $52.2 \%$ & 9 & $25.0 \%$ & 17.67 & 3.91 \\
\hline Latvia & 6 & $83.3 \%$ & 4 & $11.1 \%$ & 16.00 & 0.00 \\
\hline $\begin{array}{l}\text { Czech } \\
\text { Republic }\end{array}$ & 17 & $23.5 \%$ & 3 & $8.3 \%$ & 13.67 & 4.04 \\
\hline Slovenia & 12 & $25.0 \%$ & 3 & $8.3 \%$ & 15.00 & 0.00 \\
\hline Croatia & 8 & $37.5 \%$ & 2 & $5.6 \%$ & 16.00 & 0.00 \\
\hline Estonia & 2 & $50.0 \%$ & 1 & $2.8 \%$ & 15.00 & 0.00 \\
\hline Romania & 22 & $13.6 \%$ & 1 & $2.8 \%$ & 22.00 & 0.00 \\
\hline Ukraine & 4 & $25.0 \%$ & 1 & $2.8 \%$ & 15.00 & 0.00 \\
\hline Total & 160 & - & 36 & - & - & - \\
\hline
\end{tabular}

Source: own calculations based on data derived from GRI Database, https://database.globalreporting .org/ (accessed: 16.06.2020).

Although this analysis is not statistically representative due to the small number of cases, it sheds light on the current state of sustainability-related assurance and helps understand it better. Of the three sustainability reporting cases in Romania, only one was assured, and it gets one of the highest scores in our study, earning 22 points. However, if we consider this case an outlier, then the highest scores in our sample are Hungary (17.67 and SD 3.91) and Poland (17.00 and SD 1.48). At the bottom of our conditional ranking table is the Czech Republic. Although it shows the highest level of variation (SD 4.04), on average, companies from this state gained 13.67.

An important aspect is the analysis of company size is "the external assurance of SRs [which] is very much a large company phenomenon" (Bebbington, Unerman, and O'Dwyer 2014, p. 72). The paper testifies to that statement since there were no assured SRs companies that fall into the small and medium categories. However, our sample does include one instance when an SME submitted a sustainability report according to GRI Standards (AST for 2017, Latvia), but disappointingly, the assur- 
ers provided the report in the national language, disqualifying it from our scrutiny. Subsequently, we scrutinized exclusively large and multinational enterprises (MNEs) (Table 6).

Table 6. Differences between types of companies

\begin{tabular}{|c|c|c|c|c|c|c|c|c|c|}
\hline & \multicolumn{4}{|c|}{ Assurance scope } & \multicolumn{3}{|c|}{ Level of assurance } & \multirow{2}{*}{$\begin{array}{l}\text { Average } \\
\text { overall } \\
\text { assurance } \\
\text { quality } \\
\text { score }\end{array}$} & \multirow{2}{*}{$\begin{array}{l}\text { Standard } \\
\text { devia- } \\
\text { tion per } \\
\text { standard }\end{array}$} \\
\hline & $\begin{array}{l}\text { Specified } \\
\text { section(s) }\end{array}$ & $\begin{array}{c}\text { Entire } \\
\text { sr }\end{array}$ & $\begin{array}{l}\text { Ghg } \\
\text { only }\end{array}$ & $\begin{array}{l}\text { Not } \\
\text { speci- } \\
\text { fied }\end{array}$ & $\begin{array}{l}\text { Limited / } \\
\text { moderate }\end{array}$ & $\begin{array}{l}\text { Combi- } \\
\text { nation }\end{array}$ & $\begin{array}{c}\text { Not } \\
\text { specified }\end{array}$ & & \\
\hline Large & $76.0 \%$ & $16.0 \%$ & $0.0 \%$ & $8.0 \%$ & $100.0 \%$ & $0.0 \%$ & $0.0 \%$ & 16.48 & 1.87 \\
\hline MNE & $45.5 \%$ & $45.5 \%$ & $9.0 \%$ & $0.0 \%$ & $54.5 \%$ & $18.2 \%$ & $27.3 \%$ & 16.82 & 4.19 \\
\hline
\end{tabular}

Source: own calculations based on data derived from GRI Database, https://database.globalreporting .org/ (accessed: 16.06.2020).

Table 6 shows that MNEs clearly made more effort than large companies. MNEs assured the entire SR in almost half the cases, while large companies did it in only $16.0 \%$ of cases. Moreover, MNEs requested the highest possible level of assurance - reasonable assurance (in $18.2 \%$ cases), while large companies were satisfied with the limited/moderate assurance provided by the auditors in all cases. Last but not least, MNEs scored on average 16.82 compared with 16.48 for large companies.

Another aspect to consider is which industry the companies belong to, as the pressure from stakeholders, as well as the inherent risk for the environment in each industry, is different. It is believed that the mining and energy sectors are the most prone to "unwanted spin-off effects," and the intensity of institutional pressures on such industries is also the highest (Boiral, Heras-Saizarbitoria, and Brotherton 2019a).

While our sample does not include the mining sector, the energy sector is well represented, with 14 companies belonging to this category (eleven energy companies and three energy utilities (Table 7).

Table 7. Differences between companies by sector

\begin{tabular}{|l|c|c|c|c|c|c|c|c|c|c|}
\hline \multirow{2}{*}{ Sector } & \multirow{2}{*}{$\begin{array}{c}\text { Num- } \\
\text { ber }\end{array}$} & $\begin{array}{c}\text { Spec- } \\
\text { ified } \\
\text { sec- } \\
\text { tion(s) }\end{array}$ & $\begin{array}{c}\text { Entire } \\
\text { sr }\end{array}$ & $\begin{array}{c}\text { Ghg } \\
\text { only }\end{array}$ & $\begin{array}{c}\text { Not } \\
\text { speci- } \\
\text { fied }\end{array}$ & $\begin{array}{c}\text { Limited } \\
\text { / mod- } \\
\text { erate } \\
\text { Com- } \\
\text { bina- } \\
\text { tion }\end{array}$ & $\begin{array}{c}\text { Not } \\
\text { speci- } \\
\text { fied } \\
\text { age } \\
\text { overall } \\
\text { assur- } \\
\text { ance } \\
\text { quality } \\
\text { score }\end{array}$ & $\begin{array}{c}\text { Stand- } \\
\text { ard } \\
\text { devia- } \\
\text { tion per } \\
\text { stand- } \\
\text { ard }\end{array}$ \\
\hline Energy & 11 & $90.9 \%$ & $9.1 \%$ & $0.0 \%$ & $0.0 \%$ & $81.8 \%$ & $18.2 \%$ & $0.0 \%$ & 17.36 & 4.11 \\
\hline $\begin{array}{l}\text { Telecom- } \\
\text { munica- } \\
\text { tions }\end{array}$ & 7 & $42.9 \%$ & $57.1 \%$ & $0.0 \%$ & $0.0 \%$ & $57.1 \%$ & $0.0 \%$ & $42.9 \%$ & 16.00 & 1.41 \\
\hline $\begin{array}{l}\text { Financial } \\
\text { Services }\end{array}$ & 3 & $100.0 \%$ & $0.0 \%$ & $0.0 \%$ & $0.0 \%$ & $100.0 \%$ & $0.0 \%$ & $0.0 \%$ & 16.00 & 0.00 \\
\hline
\end{tabular}




\begin{tabular}{|l|c|c|c|c|c|c|c|c|c|c|}
\hline \multirow{2}{*}{ Sector } & \multicolumn{4}{|c|}{$\begin{array}{c}\text { Num- } \\
\text { ber }\end{array}$} & $\begin{array}{c}\text { Spec- } \\
\text { ified } \\
\text { sec- } \\
\text { tion(s) }\end{array}$ & $\begin{array}{c}\text { Entire } \\
\text { sr }\end{array}$ & $\begin{array}{c}\text { Ghg } \\
\text { only }\end{array}$ & $\begin{array}{c}\text { Not } \\
\text { speci- } \\
\text { fied }\end{array}$ & $\begin{array}{c}\text { Level of assurance } \\
\text { Limited } \\
\text { /mod- } \\
\text { erate } \\
\text { Com- } \\
\text { bina- } \\
\text { tion } \\
\text { age } \\
\text { overall } \\
\text { assur- } \\
\text { ance } \\
\text { speci- } \\
\text { fied } \\
\text { quality } \\
\text { devia- } \\
\text { tion per } \\
\text { stand- } \\
\text { ard }\end{array}$ \\
\hline $\begin{array}{l}\text { Energy } \\
\text { Utilities }\end{array}$ & 3 & $0.0 \%$ & $66.7 \%$ & $0.0 \%$ & $33.3 \%$ & $100.0 \%$ & $0.0 \%$ & $0.0 \%$ & 16.00 & 0.00 \\
\hline Logistics & 2 & $50.0 \%$ & $50.0 \%$ & $0.0 \%$ & $0.0 \%$ & $100.0 \%$ & $0.0 \%$ & $0.0 \%$ & 14.00 & 2.83 \\
\hline $\begin{array}{l}\text { Healthcare } \\
\text { Products }\end{array}$ & 2 & $50.0 \%$ & $50.0 \%$ & $0.0 \%$ & $0.0 \%$ & $100.0 \%$ & $0.0 \%$ & $0.0 \%$ & 17.50 & 2.12 \\
\hline $\begin{array}{l}\text { Miscella- } \\
\text { neous }\end{array}$ & 8 & $75.0 \%$ & $0.0 \%$ & $12.5 \%$ & $12.5 \%$ & $100.0 \%$ & $0.0 \%$ & $0.0 \%$ & 16.88 & 2.42 \\
\hline
\end{tabular}

Source: own calculations based on data derived from GRI Database, https://database.globalreporting .org/ (accessed: 16.06.2020).

Energy sector companies more often strive to get the highest level of assurance from assurance providers. In our sample, energy companies exclusively have reasonable assurance from auditors. On average, companies from this sector were assessed to have the second-highest score earning, on average (17.36), giving way only to the healthcare products sector with its 17.50 assurance quality score. Of the four cases where AA1000AS standards were applied, three are in the assurance reports of energy sector companies.

We do not know the motivation for these actions, and this is beyond the scope of our study, but we see that energy sector companies excel in sustainability-related assurance. It is not stated whether it is to do with conscious actions or pressure from stakeholders, the desire to please them and gain perceived legitimacy of their activities (Bebbington, Unerman, and O’Dwyer 2014, p. 5).

Paradoxically, however, the quality of sustainability-related assurance decreases over the years. The maximum was 19.0 for the assurance reports for 2016 and 20162017, and then each year, it slipped a little with a nadir reached for SR in 2019, when the average score was 15.7 (Table 8).

Table 8. Quality of assurance statements per year

\begin{tabular}{|c|c|c|c|c|c|c|}
\hline \multirow[b]{2}{*}{ Year } & \multicolumn{2}{|c|}{ Assured reports } & \multirow{2}{*}{$\begin{array}{l}\text { Assurance } \\
\text { quality } \\
\text { score } \\
\text { mean }\end{array}$} & \multirow[b]{2}{*}{ Sd } & \multirow[b]{2}{*}{ Min } & \multirow[b]{2}{*}{$\operatorname{Max}$} \\
\hline & $\begin{array}{c}\text { Absolute } \\
\text { count }\end{array}$ & $\begin{array}{c}\text { Relative } \\
\text { count }\end{array}$ & & & & \\
\hline 2019 & 3 & 8.3 & 15.7 & 0.6 & 15 & 16 \\
\hline 2018 & 17 & 47.2 & 15.9 & 2.6 & 9 & 21 \\
\hline 2017 and 2017-2018 & 13 & 36.1 & 17.2 & 2.3 & 15 & 22 \\
\hline 2016 and $2016-2017$ & 3 & 8.3 & 19.0 & 5.2 & 16 & 25 \\
\hline
\end{tabular}

Source: own calculations based on data derived from GRI Database, https://database.globalreporting .org/ (accessed: 16.06.2020). 
In our opinion, this can be explained by the increasing number. As the number of assurances grows, so does the number of cases in which the Big Four are auditors. They, in turn, mostly use only one standard - ISAE3000 - which, as we show later, is inferior (according to our coding rules) to AA1000AS. In our sample, AA1000AS was applied as a basis for assurance reports in 2016 (1 case), 2017 (2 cases), and 2018 (1).

Now move to the attributes of sustainability-related assurance reports that directly impact the quality of the report, namely the standards applied, the assurance provider, and the addressees of the assurance statement.

As we have already noted, there is a difference in the quality of the report depending on the standards applied (Table 9). This is especially noticeable when we split the sample into two groups: one includes AA1000AS separately or combined, and one without AA1000AS.

Table 9. Differences between applied standards

\begin{tabular}{|l|c|c|c|c|}
\hline \multirow{2}{*}{\multicolumn{1}{|c|}{ Assurance standard }} & \multicolumn{2}{|c|}{ Assured reports } & $\begin{array}{c}\text { Average overall } \\
\text { assurance quality } \\
\text { score }\end{array}$ & $\begin{array}{c}\text { Standard } \\
\text { deviation per } \\
\text { standard }\end{array}$ \\
\cline { 2 - 5 } & $\begin{array}{c}\text { Absolute } \\
\text { count }\end{array}$ & $\begin{array}{c}\text { Relative } \\
\text { count }\end{array}$ & $\begin{array}{c}75.0 \\
16.37\end{array}$ & 1.15 \\
\hline ISAE3000 & 27 & 11.1 & 14.25 & 1.50 \\
\hline Not specified & 4 & 8.3 & 22.33 & 2.31 \\
\hline $\begin{array}{l}\text { Combination (AA1000AS } \\
\text { AND ISAE3000) }\end{array}$ & 1 & 2.8 & 22.00 & 0.00 \\
\hline AA1000AS only & 1 & 2.8 & 9.00 & 0.00 \\
\hline ISRS 4400 & & & & \\
\hline
\end{tabular}

Source: own calculations based on data derived from GRI Database, https://database.globalreporting .org/ (accessed: 16.06.2020).

The use of AA1000AS and compliance with it during the assurance process significantly increases the assurance quality score. In our sample, assurance reports that apply only AA1000AS score, on average, 22.00. Combining AA1000AS with ISAE3000 produces a report with an average assurance quality score of 22.33. ISAE3000 used separately scores, on average, 16.37. However, the use of AA1000AS does not depend on whether the assurance provider belongs to the accountant or non-accountant category (Table 10).

Table 10. Differences between accountant and non-accountant assurance providers

\begin{tabular}{|l|c|c|c|c|c|}
\hline \multirow{2}{*}{$\begin{array}{c}\text { Assurance } \\
\text { provider }\end{array}$} & $\begin{array}{c}\text { Assurance } \\
\text { process } \\
\text { includes } \\
\text { aa1000as } \\
\text { standard }\end{array}$ & $\begin{array}{c}\text { Absolute } \\
\text { count }\end{array}$ & $\begin{array}{c}\text { Relative } \\
\text { count }\end{array}$ & $\begin{array}{c}\text { Average overall } \\
\text { assurance } \\
\text { quality score }\end{array}$ & $\begin{array}{c}\text { Standard } \\
\text { deviation per } \\
\text { standard }\end{array}$ \\
\cline { 3 - 6 } & $11.5 \%$ & 26 & 72.2 & 16.50 & 2.72 \\
\hline Accountants & $10.0 \%$ & 10 & 27.8 & 16.80 & 2.90 \\
\hline Non-accountants & & &
\end{tabular}

Source: own calculations based on data derived from GRI Database, https://database.globalreporting .org/ (accessed: 16.06.2020). 
In our sample, accountant or non-accountant providers made use of AA1000AS roughly equally in about $1 / 10$ cases. Similarly, there is no clear distinction between accountant or non-accountant providers based on the assurance quality score, respectively 16.50 and 16.80 .

AA1000AS was employed three times by one of the Big Four companies, Ernst \& Young, and specialized provider SK Sustainability Knowledge Group Ltd, which boasts it is an AA1100 licensed assurance provider. Yet, regardless of the assurance providers, the inclusivity of the stakeholders in the process does not play a pivotal role in most companies (Table 11).

Table 11. Differences between addressees of assurance statement

\begin{tabular}{|l|c|c|c|c|}
\hline \multirow{2}{*}{$\begin{array}{c}\text { Addressees of assurance } \\
\text { statement }\end{array}$} & \multicolumn{2}{|c|}{ Assured reports } & $\begin{array}{c}\text { Average overall } \\
\text { assurance quality } \\
\text { score }\end{array}$ & $\begin{array}{c}\text { Standard } \\
\text { deviation per } \\
\text { standard }\end{array}$ \\
\cline { 2 - 5 } Mangelute count & $\begin{array}{c}\text { Relative } \\
\text { count }\end{array}$ & 69.4 & 16.84 & 2.27 \\
\hline No addressee mentioned & 25 & 13.9 & 15.80 & 3.70 \\
\hline Stakeholders & 4 & 11.1 & 18.25 & 1.50 \\
\hline Board of directors & 1 & 2.8 & 9.00 & 0.00 \\
\hline Shareholders & 1 & 2.8 & 15.00 & 0.00 \\
\hline
\end{tabular}

Source: own calculations based on data derived from GRI Database, https://database.globalreporting .org/ (accessed: 16.06.2020).

In most cases (69.4\%), the addressee is management, again, regardless of the applicable standards. By the same token, we can assume that appealing to the board of directors ( 1 case) and shareholders (1 case), they are also considered addressees by the reporting company. Stakeholders are addressees in only four instances, constituting $11.1 \%$ of cases. Interestingly, all assurance reports that address stakeholders were provided by Bureau Veritas, a company that specializes in testing, inspection, and certification, with its headquarters in Paris, France.

\section{Limitations of the study}

Our study focused only on companies in CEE that a) are in the GRI SDD database and b) have submitted their SR reports in accordance with GRI Standards. This approach has its advantages, as it allows us to employ comprehensive sampling (all companies matching the criteria are included without any limitations) and to focus only on recent practice in the field. At the same time, however, due to the low level of proliferation of sustainability-related assurance in CEE and the filter settings used, our sample was slightly smaller than we expected, which led to a reduction in the volume of research and the cancellation of some of the elements we had planned prior. Among others, we abandoned our idea to use the auditor's suggestions for improvement as only a few reports contained them. 
Although we have taken all precautions to prevent it, a certain element of subjectivity may also be present in the coding system we use and how it was applied. We used recognized coding rules employed extensively throughout the field (O'Dwyer and Owen 2005; Perego and Kolk 2012; Gürtürk and Hahn 2016), but these coding rules are a collection of various aspects from different norms (the Account Ability, Federation of European Accountants, and GRI guidelines). It implies that the weight of different elements may vary depending on the views of the authors, and it may bear the blame for some irregularities between the studies.

In spite of the two independent coders and two authors of this paper coding the sustainability-related assurance reports in a way that we believe has ruled out any subjectivity in our assessment and made it inter-subjective, there always remains a chance that four other people might have collectively come to a different opinion than those who coded this study.

\section{Discussion and conclusions}

Sustainability reporting and sustainability-related assurance have been used by organizations in an effort to be accountable to their stakeholders. Moreover, sustainability reporting has become a lingua franca in the communication between companies and stakeholders. A better understanding of current practices is crucial for comparative and trend analyses (Junior, Best, and Cotter 2014).

This study reviewed the sustainability-related assurance reports from companies based in the CEE region. This paper demonstrates that organizations in CEE use SRs assured by auditors to provide accountability about their environmental and social performance. Although those efforts are made irrespective of geographic location and the level of economic development of the country they are based in, sustainability-related assurances of companies were analyzed in only nine of the fifteen countries studied.

Employing the modified coding rules from prior research, a conventional content analysis of 36 assurance statements was conducted. To the best of our knowledge, this paper is a pioneer in examining current sustainability-related assurance practices in CEE.

Although companies from nine countries were the subject of the study, it should be noted that more than half of all sustainability reporting (55.6\%) and assurance statements accompanying them (58.3\%) come from two countries Poland and Hungary, with the former outnumbering the latter.

The overall mean of our study is 16.58 , with a standard deviation of 2.73 . The most comprehensive statements in the sample scored 25 points, while the least transparent managed to get only nine points with the maximum score achievable 35 points. We scrutinized exclusively large and multinational enterprise (MNE) companies. In this regard, we conclude that MNEs clearly made an effort more than large companies. Energy sector companies more often strive to get the highest level of assurance 
from assurance providers, which is testified by the fact that in our sample, exclusively energy companies have reasonable assurance from auditors (as opposed to the prevailing limited/moderate assurance). On average, companies from the energy sector were assessed to have the second-highest score, earning, on average, 17.36. They were second only to the healthcare products sector with its 17.50 assurance quality score. Furthermore, of the four cases of applying AA1000AS standards in our sample, three are in assurance reports of energy sector companies.

The quality of sustainability-related assurance declines over the years, from 19.0 (2016 and 2016-2017) to 15.7 (2019). The difference in the quality of the assurance report is particularly conspicuous on the dividing line between those with and without AA1000AS. Compliance with AA1000AS boosts assurance quality scores a good deal. Similarly, there is no clear distinction between accountant or non-accountant providers based on assurance quality scores, respectively, 16.50 and 16.80. In most cases, the addressee is management, while stakeholders are addressees in only four instances, constituting $11.1 \%$ of cases.

The vast majority of assurance providers belong to the Big Four, who use ISAE3000, which, based on our coding rules, we found to be inferior in quality compared to AA1100AS. Yet, irrespective of the assurance provider types, we found that the stakeholders are neglected. Yet, the opposite situation should be the case for sustainability-related assurance to play the role it purports to. We want to issue a warning that the pursuit of conventional business agendas, which are in fundamental conflict with environmental protection, could lead to a situation when "accounting is contributing to environmental degradation - not environmental protection" (Gray and Bebbington 2000, pp. 1-2).

We strongly believe that just transferring the experience of financial auditing to the field of sustainability, which by and large has taken place now, is not an option. We believe that following this route, we are heading in the wrong direction. In technical terms, the wider proliferation of AA1100AS and its principles, with greater emphasis on reasonable assurance as opposed to the limited and enhanced role of stakeholders, are vital to get back on track.

It is a complex problem, and much also depends on the pressure from society, the development of the sustainability assurance providers profession, and development of self-regulation of this profession. For example, the fee level for sustainability assurance is just a tiny "fraction (usually less than 10\%) of financial audit fees" (Bebbington, Unerman, and O'Dwyer 2014, p. 79). This certainly brings "into doubt the ability of the sustainability assurors to carry out the necessary amount of substantive testing to justify a positive form conclusion" (Bebbington, Unerman, and O'Dwyer 2014, p. 79).

For the CEE region, the situation is slightly more complicated because due to the insufficient proliferation of sustainability reporting and assurance, it is lagging behind Western Europe and North America. Since sustainability reporting is not mandatory in the region, it is only the ever-increasing pressure from civil society and the public that will sway companies to be active in this field. If there is demand, then there will be supply. 
Despite some early indications of the relationship between different attributes of assurance statements and their quality, the sample size, data analysis (reliance on released assurance reports only), and the qualitative approach of the study prevent us from any form of general assumptions.

One of the recommendations for further research in this direction, based on this, would be a combination of the qualitative and quantitative approaches. Furthermore, content analysis is used mostly as a quality tool while we believe that interviews with assurance providers and stakeholders would shed much light and even open up new areas of research in the field. We encourage researchers to move in this direction.

\section{References}

Ackers, B. (2017a), Independent corporate social responsibility assurance: a response to soft laws, or influenced by company size and industry sector?, "International Journal of Disclosure and Governance”, 14, pp. 278-298, https://doi.org/10.1057/s41310 -017-0026-7

Ackers, B. (2017b), The Evolution of Corporate Social Responsibility Assurance - A Longitudinal Study, "Social and Environmental Accountability Journal", 37 (2), pp. 97117, https://doi.org/10.1080/0969160X.2017.1294097

Bebbington, J., Unerman, J., O’Dwyer, B. (2014), Sustainability Accounting and Accountability, Routledge, London, https://doi.org/10.4324/9781315848419

Boiral, O., Gendron, Y. (2011), Sustainable Development and Certification Practices: Lessons Learned and Prospects, "Business Strategy and the Environment", 20 (5), pp. 331-347, https://doi.org/10.1002/bse.701

Boiral, O., Heras-Saizarbitoria, I. (2020), Sustainability reporting assurance: Creating stakeholder accountability through hyperreality?, "Journal of Cleaner Production", 243, 118596, https://doi.org/10.1016/j.jclepro.2019.118596

Boiral, O., Heras-Saizarbitoria, I., Brotherton, M.-C. (2019a), Assessing and Improving the Quality of Sustainability Reports: The Auditors' Perspective, "Journal of Business Ethics”, 155 (3), pp. 703-721, https://doi.org/10.1007/s10551-017-3516-4

Boiral, O., Heras-Saizarbitoria, I., Brotherton, M.-C. (2019b), Professionalizing the assurance of sustainability reports: the auditors' perspective, "Accounting, Auditing \& Accountability Journal”, 33 (2), pp. 309-334, https://doi.org/10.1108/AAAJ-03 $-2019-3918$

Channuntapipat, C., Samsonova-Taddei, A., Turley, S. (2019), Exploring diversity in sustainability assurance practice, "Accounting, Auditing \& Accountability Journal", 32 (2), pp. 556-580, https://doi.org/10.1108/AAAJ-05-2017-2940

Channuntapipat, C., Samsonova-Taddei, A., Turley, S. (2020), Variation in sustainability assurance practice: An analysis of accounting versus non-accounting providers, "The British Accounting Review", 52 (2), 100843, https://doi.org/10.1016/j.bar .2019 .100843

Farooq, M.B., Villiers, C. de (2019a), How sustainability assurance engagement scopes are determined, and its impact on capture and credibility enhancement, "Account- 
ing, Auditing \& Accountability Journal", 33 (2), pp. 417-445, https://doi.org/10.11 08/AAAJ-11-2018-3727

Farooq, M.B., Villiers, C. de (2019b), Sustainability Assurance: Who Are the Assurance Providers and What Do They Do?, [in:] S. Arvidsson (ed.), Challenges in Managing Sustainable Business, Springer International Publishing, Cham, pp. 137-154, https:// doi.org/10.1007/978-3-319-93266-8_6

Farooq, M.B., Villiers, C. de (2019c), The shaping of sustainability assurance through the competition between accounting and non-accounting providers, "Accounting, Auditing \& Accountability Journal", 32 (1), pp. 307-336, https://doi.org/10.1108/AA AJ-10-2016-2756

Fédération des Experts Comptables Européens (2006), Key issues in sustainability assurance an overview. https://www.accountancyeurope.eu/wp-content/uploads/FEE _DP_Key_Issues_in_Sustainability_Assurance_-_An_Overview_06061362006441 152.pdf (accessed: 19.06.2020).

Gilbert, D.U., Rasche, A., Waddock, S. (2011), Accountability in a Global Economy: The Emergence of International Accountability Standards, "Business Ethics Quarterly", 21 (1), pp. 23-44, https://doi.org/10.5840/beq20112112

Gray, R., Bebbington, J. (2000), Environmental accounting, managerialism and sustainability: Is the planet safe in the hands of business and accounting?, "Advances in Environmental Accounting \& Management", 1, pp. 1-44, https://doi.org/10.10 16/S1479-3598(00)01004-9

GRI Database, https://database.globalreporting.org/ (accessed: 16.06.2020).

Gürtürk, A., Hahn, R. (2016), An empirical assessment of assurance statements in sustainability reports: smoke screens or enlightening information?, "Journal of Cleaner Production", 136 (A), pp. 30-41, https://doi.org/10.1016/j.jclepro.2015.09.089

Hahn, R., Kühnen, M. (2013), Determinants of sustainability reporting: a review of results, trends, theory, and opportunities in an expanding field of research, "Journal of Cleaner Production", 59, pp. 5-21, https://doi.org/10.1016/j.jclepro.2013.07.005

Haider, M.B., Nishitani, K. (2020), Views of corporate managers on assurance of sustainability reporting: evidence from Japan, "International Journal of Disclosure and Governance", 17 (1), pp. 1-19, https://doi.org/10.1057/s41310-019-00070-0

Hsieh, H.-F., Shannon, S.E. (2005), Three Approaches to Qualitative Content Analysis, "Qualitative Health Research", 15 (9), pp. 1277-1288, https://doi.org/10.1177/1049 732305276687

Jones, M.J., Solomon, J.F. (2010), Social and environmental report assurance: Some interview evidence, "Accounting Forum", 34 (1), pp. 20-31, https://doi.org/10.1016/j.ac cfor.2009.11.002

Junior, R.M., Best, P.J., Cotter, J. (2014), Sustainability Reporting and Assurance: A Historical Analysis on a World-Wide Phenomenon, "Journal of Business Ethics", 120 (1), pp. 1-11, https://doi.org/10.1007/s10551-013-1637-y

KPMG (2017), The road ahead. The KPMG Survey of Corporate Responsibility Reporting 2017, https://assets.kpmg/content/dam/kpmg/be/pdf/2017/kpmg-survey-of-cor porate-responsibility-reporting-2017.pdf (accessed: 18.05.2020).

Larrinaga, C., Rossi, A., Luque-Vilchez, M., Núñez-Nickel, M. (2020), Institutionalization of the Contents of Sustainability Assurance Services: A Comparison Between 
Italy and United States, "Journal of Business Ethics", 163 (1), pp. 67-83, https://doi .org/10.1007/s10551-018-4014-z

Maroun, W. (2019), Does external assurance contribute to higher quality integrated reports?, "Journal of Accounting and Public Policy", 38 (4), 106670, https://doi.org/10 .1016/j.jaccpubpol.2019.06.002

Maroun, W. (2020), A Conceptual Model for Understanding Corporate Social Responsibility Assurance Practice, "Journal of Business Ethics”, 161 (1), pp. 187-209, https:// doi.org/10.1007/s10551-018-3909-Z

Michelon, G., Patten, D.M., Romi, A.M. (2019), Creating Legitimacy for Sustainability Assurance Practices: Evidence from Sustainability Restatements, "European Accounting Review”, 28 (2), pp. 395-422, https://doi.org/10.1080/09638180.2018.146 9424

Mikołajek-Gocejna, M. (2016), Zależność między społeczna odpowiedzialnością przedsiębiorstw a ich wynikami finansowymi - dowody a badań empirycznych, "Comparative Economic Research. Central and Eastern Europe”, 19 (4), pp. 67-84, https:// doi.org/10.1515/cer-2016-0030

Mikołajek-Gocejna, M. (2018), Środowiskowy, społeczny i zarządczy aspekt indeksów społecznej odpowiedzialności - analiza porównawcza europejskich indeksów SRI, "Comparative Economic Research. Central and Eastern Europe", 21 (3), pp. 25-44, https://doi.org/10.2478/cer-2018-0017

Mock, T.J., Rao, S.S., Srivastava, R.P. (2013), The Development of Worldwide Sustainability Reporting Assurance, "Australian Accounting Review", 23 (4), pp. 280-294, https://doi.org/10.1111/auar.12013

Moroney, R., Windsor, C., Aw, Y.T. (2012), Evidence of assurance enhancing the quality of voluntary environmental disclosures: an empirical analysis, "Accounting \& Finance”, 52 (3), pp. 903-939, https://doi.org/10.1111/j.1467-629X.2011.00413.x

Nishitani, K., Haider, M.B., Kokubu, K. (2020), Are third-party assurances preferable to third-party comments for promoting financial accountability in environmental reporting?, "Journal of Cleaner Production", 248, 119199, https://doi.org/10.1016/j.jc lepro.2019.119199

O’Dwyer, B., Owen, D.L. (2005), Assurance statement practice in environmental, social and sustainability reporting: a critical evaluation, "The British Accounting Review", 37 (2), pp. 205-229, https://doi.org/10.1016/j.bar.2005.01.005

O’Dwyer, B., Owen, D. (2007), Seeking Stakeholder-Centric Sustainability Assurance, "Journal of Corporate Citizenship", 25, pp. 77-94.

O’Dwyer, B., Owen, D., Unerman, J. (2011), Seeking legitimacy for new assurance forms: The case of assurance on sustainability reporting, "Accounting, Organizations and Society", 36 (1), pp. 31-52, https://doi.org/10.1016/j.aos.2011.01.002

Park, J., Brorson, T. (2005), Experiences of and views on third-party assurance of corporate environmental and sustainability reports, "Journal of Cleaner Production", 13 (10-11), pp. 1095-1106, https://doi.org/10.1016/j.jclepro.2004.12.006

Perego, P., Kolk, A. (2012), Multinationals" Accountability on Sustainability: The Evolution of Third-party Assurance of Sustainability Reports, "Journal of Business Ethics”, 110 (2), pp. 173-190, https://doi.org/10.1007/s10551-012-1420-5 
Power, M. (1997), Expertise and the construction of relevance: Accountants and environmental audit, "Accounting, Organizations and Society", 22 (2), pp. 123-146, https:// doi.org/10.1016/S0361-3682(96)00037-2

Power, M. (1999), The Audit Society, Oxford University Press, Oxford, https://doi.org /10.1093/acprof:oso/9780198296034.001.0001

Quick, R., Inwinkl, P. (2020), Assurance on CSR reports: impact on the credibility perceptions of non-financial information by bank directors, "Meditari Accountancy Research", 28 (5), pp. 833-862, https://doi.org/10.1108/MEDAR-10-2019-0597

Rossi, A., Tarquinio, L. (2017), An analysis of sustainability report assurance statements, "Managerial Auditing Journal", 32 (6), pp. 578-602, https://doi.org/10.1108 /MAJ-07-2016-1408

Ruiz-Barbadillo, E., Martínez-Ferrero, J. (2020), Empirical analysis of the effect of the joint provision of audit and sustainability assurance services on assurance quality, "Journal of Cleaner Production", 266, 121943, https://doi.org/10.1016/j.jclepro.20 20.121943

Safari, M., Areeb, A. (2020), A qualitative analysis of GRI principles for defining sustainability report quality: an Australian case from the preparers' perspective, "Accounting Forum”, 44 (4), pp. 344-375, https://doi.org/10.1080/01559982.2020.1736759

Smith, J., Haniffa, R., Fairbrass, J. (2011), A Conceptual Framework for Investigating "Capture" in Corporate Sustainability Reporting Assurance, "Journal of Business Ethics”, 99, pp. 425-439, https://doi.org/10.1007/s10551-010-0661-4

Stocker, F., Arruda, M.P. de, Mascena, K.M.C. de, Boaventura, J.M.G. (2020), Stakeholder engagement in sustainability reporting: A classification model, "Corporate Social Responsibility and Environmental Management”, 27 (5), pp. 2071-2080, https:// doi.org/10.1002/csr.1947

Zorio, A., García-Benau, M.A., Sierra, L. (2013), Sustainability Development and the Quality of Assurance Reports: Empirical Evidence, "Business Strategy and the Environment”, 22 (7), pp. 484-500, https://doi.org/10.1002/bse.1764

\section{Odpowiedzialność w zakresie zrównoważonego rozwoju w Europie Środkowej i Wschodniej: empiryczna ocena audytu zrównoważonego rozwoju}

Artykuł poddaje analizie działania firm z Europy Środkowej i Wschodniej polegające na audycie służącym zapewnieniu odpowiedzialności za realizację zasad zrównoważonego rozwoju. W oparciu o zmodyfikowane zasady kodowania wykorzystane we wcześniejszych badaniach, przeprowadzono konwencjonalną analizę treści oświadczeń dotyczących wiarygodności z 36 firm pochodzących z dziewięciu krajów. Wyniki wskazują na różnice $w$ treści raportów, procesach i sposobach wdrażania standardów.

Wyłącznie duże i wielonarodowe przedsiębiorstwa z sektorów energetycznych z siedzibą w Polsce i na Węgrzech stanowią w badanej próbie typowy przykład firmy dążącej do stworzenia i poddania się audytowi sprawozdawczości dotyczącej zapewnienia zrównoważonego rozwoju. Spośród dziewięciu krajów reprezentowanych w badaniu, 
oświadczenia dotyczące wiarygodności sprawozdań o zapewnieniu zrównoważonego rozwoju firm pochodzących z Polski, Węgier i Rumunii wyróżniają się pod względem jakości. Zdecydowana większość firm audytujących należy do Wielkiej Czwórki, która wykorzystuje ISAE3000 a nie AA1100AS. Jednak niezależnie od typu podmiotu audytującego, interesariusze są zaniedbywani. Argumentuje się, że zwykłe przeniesienie doświadczeń z audytu finansowego do dziedziny zrównoważonego rozwoju, co w zasadzie już nastąpiło, nie jest dobrym rozwiązaniem. Autorzy twierdzą, że podążając tą drogą, podążamy w złym kierunku, a pod względem technicznym, szersze rozpowszechnienie AA1100AS i jego zasad, z większym naciskiem na uzyskanie wysokiej jakości oceny, a nie ograniczanie i zwiększanie roli interesariuszy, jest niezbędne aby wrócić na właściwą drogę.

Artykuł stanowi wkład do powstającej literatury na temat standardów odpowiedzialności i podkreśla potrzebę zwiększenia jakości audytu w obszarze zapewnienia zrównoważonego rozwoju.

Słowa kluczowe: raportowanie zrównoważonego rozwoju, oświadczenie dotyczące wiarygodności, GRI, społeczna odpowiedzialność biznesu, raportowanie, audyt 